\title{
Analisis Penerapan Standar Akuntansi Keuangan Entitas Tanpa Akuntabilitas Publik pada Badan Usaha Milik Desa Selat
}

\author{
Ketut Suci Cahyani $^{*}$, Ni Kadek Sinarwati ${ }^{2}$ iD \\ ${ }^{12}$ Program Studi S1 Akuntansi, Jurusan Ekonomi dan Akuntansi, Universitas Pendidikan Ganesha, Singaraja, Indonesia \\ *sucicahyani966@gmail.com*
}

\section{Abstrak}

Penelitian ini bertujuan mengetahui: 1) Alasan BUMDesa tidak menerapkan SAK ETAP, 2) Penerapan SAK ETAP pada BUMDesa Selat Kabupaten Buleleng, 3) Implementasi penerapan SAK ETAP terhadap laporan keuangan. Penelitian ini dilakukan dengan metode deskriptif kualitatif. Sumber data yang digunakan yaitu data primer dan data sekunder. Penelitian ini dilakukan dalam empat tahapan: 1) Pengumpulan data, 2) Reduksi data, 3) Penyajian data, 4) analisis data dan penarikan kesimpulan. Hasil penelitian menunjukkan bahwa: 1) Alasan BUMDesa Pandan Harum tidak menerapkan SAK ETAP pada laporan keuangannya karena ketidakmampuan sumber daya manusia, dan kurangnya kesadaran terhadap pentingnya laporan keuangan yang lengkap dan sesuai dengan SAK ETAP, 2) Penerapan SAK ETAP pada BUMDesa Pandan Harum dalam penyusunan laporan keuangan yaitu laporan laba rugi menunjukkan bahwa BUMDesa mengalami laba sebesar Rp 77.583.792,00, Laporan neraca menunujukkan bahwa jumlah aktiva sebesar Rp 1.184.806.431,37 dan jumlah passive sebesar Rp 1.184.806.431,37, laporan perubahan ekuitas menunjukkan saldo sebesar Rp 1.242.987.240,38, Laporan arus kas menunjukkan saldo sebesar Rp 1.247.358.002,38, 3) Implementasi penerapan SAK ETAP terhadap laporan keuangan yaitu memberikan format laporan keuangan yang sesuai dengan SAK ETAP yang berlaku.

Kata Kunci : Laporan Keuangan, SAK ETAP, BUMDesa

\section{Abstract}

This study aimed to find out: 1) the reasons why BUMDesa does not apply SAK ETAP, 2) Implementation of SAK ETAP on BUMDesa Selat, Buleleng Regency, 3) implementation og the implementation of SAK ETAP in financial statements. This research was conducted with a qualitative descriptive method. Sources of data used are primary data and secondary data. This research was conducted in four stages :1) data collection, 2) data reduction, 3) data display, 4) verification. The results of the study show that: 1) the reason BUMDesa Pandan Harum does not apply SAK ETAP to its financial statements is because of the incompetence of human resources, and lack of awareness of the importance of complete financial statements and in accordance with SAK ETAP, 2) application of SAK ETAP at BUMDesa Pandan Harum in the preparation of financial statements, namely the income statement, show that the BUMDesa has a profit of Rp 77.583.792,00, the balance sheet shows that the total assets are $R p$ 1.184.806.431,37 and the passive amount is $r p$ 1.184.806.431,37, the statement of changes in equity shows a balance of the $R p$ 1.242.987.240,38, the cash flow statement shows a balance of $R p$ 1.247.358.002,38, 3) Implementation of the application of SAK ETAP to financial reports, namely providing a financial report format that is in accordance with the applicable SAK ETAP.

Keywords: Financial Statements, SAK ETAP, BUMDesa

\section{Pendahuluan}

Era globalisasi serta tuntutan reformasi yang semakin meningkat, membutuhkan peran akuntansi sebagai alat pencatatan semakin dibutuhkan. Kepentingan itu tidak hanya diperuntukkan untuk pihak manajemen suatu entitas, tetapi juga untuk kebutuhan pertanggungjawaban (accountability) kepada banyak pihak yang memerlukan. Akuntansi 
merupakan sistem informasi yang mengukur aktivitas bisnis, mengolah data menjadi laporan dan mengkomunikasikan hasilnya kepada para pengambil keputusan. (Bahri, 2016).

Peraturan pemerintah (PP) No. 11 Tahun 2021 mewajibkan BUMDesa menyusun laporan keuangan seluruh unit usaha BUMDesa setiap bulan dengan jujur dan transparan. Selain itu, BUMDesa juga wajib memberikan laporan perkembangan unit usaha BUMDesa kepada masyarakat desa melalui musyawarah desa sekurang-kurangnya dua kali dalam setahun. Laporan keuangan dapat digunakan untuk mengetahui perkembangan BUMDesa dari waktu ke waktu, baik perkembangan omzet penjualan laba/rugi maupun struktur permodalan.

BAB 10 pasal 87 Undang-undang No. 6 tahun 2014 menyatakan desa dapat mendirikan Badan Usaha Milik Desa yang disebut BUMDesa, BUMDesa dikelola dengan semangat kekeluargaan dan kegotongroyongan dan dapat menjalankan usaha dibidang ekonomi atau pelayanan umum sesuai dengan ketentuan peraturan perundang-undangan. Badan Usaha Milik Desa merupakan lembaga usaha desa yang dikelola oleh masyarakat dan pemerintahan desa dalam upaya memperkuat perekonomian desa dan dibentuk berdasarkan kebutuhan potensi desa. Dasar pembentukan BUMDesa sebagai lokomotif pembangunan di desa lebih dilatar belakangi pada prakarsa pemerintah dan masyarakat desa dengan berdasarkan prinsip kooperatif , partisipatif dan emansipatif, transparansi, akuntabel dan sustainable dari masyarakat desa. Oleh karena itu perlu upaya serius untuk menjadikan pengelolaan BUMDesa dapat berjalan secara efektif, efisien, professional dan mandiri. (Buku Pedoman Pendirian dan Pengelolaan BUMDesa).

Ikatan Akuntan Indonesia (IAI) telah menerbitkan standar dalam laporan keuangan. Standar penyusunan laporan keuangan berupa Pernyataan Standar Akuntansi Keuangan (PSAK) dan Standar Akuntansi Keuangan Entitas Tanpa Akuntabilitas Publik (SAK ETAP). SAK ETAP ini dapat mempermudah dalam penyusunan laporan keuangan dan diharapkan menjadi solusi permasalahan internal perusahaan terutama bagi manajemen yang hanya melihat laba yang diperoleh tanpa melihat kondisi keuangan yang sebenarnya. (IAI:2009)

SAK ETAP merupakan salah satu standar keuangan yang ditetapkan untuk mempermudah UMKM dalam menyusun dan menyajikan laporan keuangan yang lebih informative dengan tujuan memberikan kemudahan bagi investor maupun kreditor untuk memberikan bantuan pembiayaan bagi para pengusaha UMKM. Salah satu dampak dari penerapan SAK ETAP adalah terjadinya peningkatan dalam efisiensi, efektivitas dan produktivitas usaha. Selanjutnya perusahaan kecil dan menengah diharapkan dapat menyusun laporan keuangan sendiri, dapat diaudit dan mendapatkan opini audit sehingga perusahaan dapat menggunakan laporan keuangannya untuk mendapatkan dana atau modal untuk pengembangan desanya. (Seran, 2017).

Adanya keterbatasan pengetahuan pencatatan akuntansi, rumitnya proses akuntansi dan berbagai macam keterbatasan yang di hadapi oleh UMKM dalam menyusun laporan keuangan yakni kurang disiplin dan rajinnya dalam pelaksanaan pembukuan akuntansi, tidak adanya kecukupan dana untuk memperkerjakan akuntan atau membeli software akuntansi untuk mempermudah pelaksanaan pembukuan akuntansi, kurangnya sosialisasi tentang penerapan SAK ETAP yang membuat pelaku bisnis kecil menengah masih takut menggunakan SAK ETAP dan tidak adanya peraturan yang mewajibkan penyusunan laporan bagi UMKM menyebabkan rendaknya praktek akuntansi pada UMKM di Indonesia. (Sinarwati, 2014).

Implementasi Undang-undang No. 6 tahun 2014 tentang desa telah melahirkan ribuan Badan Usaha Milik Desa. Namun, dalam penetapan kebijakan pelaksanaan dan pengelolaan BUMDesa masih banyak dijumpai masalah yang dihadapi antara lain terkait dengan aspek manajemen, standar akuntansi keuangan dan legalitas hukum. Badan Usaha milik Desa 
dibentuk oleh pemerintah desa untuk memanfaatkan segala potensi ekonomi serta potensi sumber daya alam dan sumber daya manusia guna meningkatkan kesejahteraan masyarakat pedesaan. Terkait persoalan keuangan, Standar Akuntansi Keuangan untuk Entitas Tanpa Akuntabilitas Publik akan diterapkan dalam pengelolaan keuangan BUMDesa.

Aturan atau teori yang menyatakan bahwa BUMDesa harus menyusun laporan keuangan berdasarkan SAK ETAP tidak ada yang terpenting BUMDesa sudah menyusun laporan keuangan. Tetapi karena BUMDesa merupakan suatu entitas dan temuan (Sinarwati dan Marhaeni, 2019) menemukan bahwa BUMDesa berperan bagi pembangunan pedesaan maka layak jika menyusun laporan keuangan menggunakan SAK ETAP dan tidak menggunakan ISAK 35. Meskipun tidak ada keharusan, tetapi jika daripada BUMDesa tidak menyusun laporan keuangan yang dapat digunakan sebagai alat pertanggungjawaban dana terhadap pemerintah, maka solusi penyusunan laporan keuangan menggunakan SAK ETAP merupakan salah satu solusi yang layak untuk dilakukan meski ditemukan sebenarnya akan berguna jangka pendek.

Tujuan dari penyusunan SAK ETAP bukan hanya sebagai standar keuangan yang layak bagi perusahaan dan menengah atau perusahaan go public termasuk BUMDesa. Pengelolaan keuangan masih banyak BUMDesa yang sudah berkembang yang belum menerapkan SAK ETAP dalam laporan keuangannya, karena dari beberapa masih memiliki anggapan bahwa informasi akuntansi tersebut tidak penting, tidak akan berdampak pada kondisi keuangan mereka dan sulit diterapkan dan juga membuang waktu dan biaya. Hal terpenting bagi pengelola usaha adalah bagaimana cara menghasilkan laba yang banyak tanpa repot menerapkan akuntansi.

Kenyataannya pengelolaan keuangan pada beberapa BUMDesa yang sudah berkembang terutama dalam hal penyusunan laporan keuangan masih belum ada ketetapan yang mengharuskan mengacu pada SAK ETAP. Padahal jika BUMDesa membuat laporan keuangan sesuai dengan pedoman SAK ETAP, laporan keuangan lebih fleksible dan beberapa aspek terlihat lebih ringan dan mudah dipergunakan. Hal ini dibuktikan dalam penelitian (Hamzah et al., 2019) dalam penelitiannya menyatakan bahwa pencatatan (jurnal) atas berbagai transaksi yang dilakukan penggolongan transaksi pada BUMDesa Langktin belum sesuai dengan SAK ETAP. BUMDesa Langkitin menggunakan jurnal memorial untuk peringkasan neraca percobaan untuk pengiktisaran sehingga belum sesuai dengan SAK ETAP. BUMDesa Langkitin menyajikan laporan keuangan hanya dalam dua jenis yaitu neraca dan laporan laba rugi sedangkan menurut SAK ETAP ada lima jenis yaitu neraca, laporan laba rugi, laporan perubahan ekuitas, laporan arus kas dan catatan atas laporan keuangan.

Pada penelitian ini peneliti memutuskan BUMDesa Pandan Harum Desa Selat sebagai obyek penelitian. Alasan peneliti melakukan penelitian di BUMDesa Pandan Harum Desa Selat karena berdiri paling lama yaitu tahun 2011, memiliki potensi yang banyak yang dapat meningkatkan asset yang dimiliki, modal yang digunakan bermodal nol rupiah atau tanpa modal yang mampu berkembang dengan pesat, memiliki keunikan yaitu memiliki kawasan hutan yang luas yang berpotensi dapat dijadikan kebun raya dan memiliki unit usaha gerbang sadu yang mampu berupaya mendorong pembangunan desa yang berbasis pada social ekonomi masyarakat.

BUMDesa Pandan Harum Desa Selat merupakan badan usaha yang dapat meningkatkan pengolahan potensi desa sesuai dengan kebutuhan masyarakat dan meningkatkan pertumbuhan dan pemerataan ekonomi pedesaan. Pada hasil observasi awal yang dilakukan peneliti di BUMDesa Pandan Harum Desa menemukan beberapa permasalahan seperti: pada penerapan laporan keuangan yang masih belum berdasarkan SAK ETAP. Apabila suatu lembaga atau organisais telah menerapkan laporan keuangan sesuai dengan SAK ETAP dapat diindikasikan telah menyajikan laporan keuangan secara lengkap, 
relevan dan dapat dipertanggung jawabkan. BUMDesa Pandan Harum Desa Selat melakukan pencatatan keuangan hanya berdasarkan pemahaman. Adapun laporan keuangan yang dibuat BUMDesa Pandan Harum Desa Selat: Laporan neraca dan laporan laba/rugi.

Berdasarkan pemaparan di atas sangat diperlukan penelitian tentang Analisis Penerapan Standar Akuntansi Keuangan Entitas Tanpa Akuntabilitas Publik pada Badan Usaha Milik Desa Selat Kabupaten Buleleng. Berbeda dengan penelitian sebelumnya, didalam penelitian ini akan membahas secara luas bukan hanya dari keberadaan BUMDesa tetapi akan melihat mengapa BUMDesa tidak menerapkan SAK ETAP dalam penyusunan laporan keuangan, bagaimana penerapan SAK ETAP pada BUMDesa Selat Kabupaten Buleleng, bagaimana implementasi penerapan SAK ETAP pada BUMDesa Selat Kabupaten Buleleng dan berbeda dari segi waktu dan tempat.

Tujuan penelitian ini untuk mengetahui alasan BUMDesa tidak menerapkan SAK ETAP dalam penyusunan laporan keuangan, mengetahui penerapan SAK ETAP pada BUMDesa Selat Kabupaten Buleleng dan mengetahui implementasi penerapan SAK ETAP pada BUMDesa Selat Kabupaten Buleleng.

\section{Metode}

Penelitian ini menggunakan metode penelitian deskriptif kualitatif. Penelitian kualitatif merupakan penelitian bersifat deskriptif dan cenderung menggunakan analisis serta hasil penelitian kualitatif tidak menekankan pada generalisasi, tetapi lebih menekankan pada makna (Sugiyono, 2015). Metode deskriptif dipilih karena penelitian yang dilakukan adalah berkaitan dengan peristiwa-peristiwa yang sedang berlangsung dan berkenaan dengan kondisi sekarang. Penelitian ini menggunakan pendekatan deskriptif dalam meneliti dan menganalisa untuk memaparkan hasil wawancara yang dilakukan dilapangan mengenai penerapan Standar Akuntansi Keuangan Entitas Tanpa Akuntabilitas Publik pada Badan Usaha Milik Desa Pandan Harum Desa Selat Kabupaten Buleleng. Sumber data yang digunakan dalam penelitian ini adalah: 1) data primer diperoleh dengan mencari data kelapangan untuk mendapatkan informasi yang berkaitan dengan penelitian dengan mengadakan wawancara langsung dengan Ketua BUMDesa dan Bendahara BUMDesa sebagai obyek penelitian. 2) data sekunder diperoleh melalui data yang telah diteliti dan dikumpulkan oleh pihak lain yang berkaitan dengan permasalahan penelitian.

Metode pengumpulan data yang digunakan yaitu: metode observasi, wawancara dan dokumentasi. Dalam proses penelitian, peneliti menggunakan alat bantu mengumpulkan data yaitu berupa buku catatan, handphone untuk merekam pembicaraan dengan informan, pedoman wawancara maupun perangkat observasi selama proses penelitian.

Uji keabsahan data dilakukan untuk membuktikan apakah penelitian yang dilakukan benar-benar merupakan penelitian ilmiah sekaligus untuk menguji data yang diperoleh. Uji keabsahan data dalam penelitian kualitatif meliputi: Uji Credibility, Transferability, Dependability dan Confirmability (Sugiyono, 2015:366). Pada penelitian ini uji keabsahan data yang dapat dilakukan adalah: 1) Kepercayaan (Credibility) merupakan uji terhadap data hasil penelitian yang disajikan oleh peneliti agar hasil penelitian yang dilakukan tidak meragukan sebagai sebuah karya ilmiah. 2) Keteralihan (Transferability) menunjukkan derajat ketepatan atau diterapkannya hasil penelitian ke populasi dimana sampel tersebut diambil, 3) Kebergantungan (Dependability) dalam hal ini peneliti meneliti dan menguji kembali hasil penelitian melalui proses pemeriksaan yang cermat dan teliti terhadap seluruh komponen dalam laporan hasil penelitian untuk memperbaiki kesalahan, sehingga hasil penelitian ini dapat mencapai kesempurnaan, 4) Kepastian (Confirmability) untuk mewujudkan kepastian maka peneliti akan mendiskusikan dan mengkonfirmasi dengan pembimbing, lebih lanjut setiap tahapan dalam penulisan penelitian ini maupun konsep yang 
dihasilkan dari lapangan dikonsultasikan dengan pembimbing sehingga diperoleh masukan untuk menambah kepastian dari hasil penelitian.

Teknik analisis data dalam penelitian ini menggunakan beberapa teknik: 1) Pengumpulan data, 2) Reduksi data, 3) Penyajian data, 4) Penarikan kesimpulan, dimana kesimpulan penelitian data kualitatif menjawab dari rumusan masalah yang telah dirumuskan diawal dalam peneliian ini, tetapi mungkin juga tidak karena rumusan masalah dalam penelitian kualitatif masih bersifat sementara.

\section{Hasil dan Pembahasan}

\section{Sejarah Berdiri BUMDesa Pandan Harum}

BUMDesa Pandan Harum Desa Selat Kabupaten Buleleng merupakan badan usaha yang berada dibawah naungan pemerintah desa Selat yang dasarnya merupakan bentuk konsolidasi atau penguatan terhadap lembaga-lembaga ekonomi desa. BUMDesa Pandan Harum beralamat dijalan Selat'Anturan Kecamatan Sukasada, Kabupaten Buleleng, Bali. BUMDesa Pandan Harum Desa Selat berdiri pada tanggal 10 Februari 2011 bermodalkan nol rupiah atau tanpa modal. Walaupun demikian bukan berarti BUMDesa ini akan sulit berkembang, melainkan mampu berkembang dengan pesat. Hal ini dibuktikan dengan berkembangnya unit-unit usaha baru yang dikelola oleh BUMDesa Pandan Harum Desa Selat serta meningkatnya asset yang dimiliki.

Permasalahan yang terjadi di BUMDesa Pandan Harum salah satunya seperti: pipa induk air yang masih perlu diperbaharui mengingat sering terjadinya kebocoran, kesadaran untuk pembayaran bunga serta pokok pinjaman masyarakat selaku peminjam Simpan Pinjam sangat kurang maka banyak terjadi tunggakan di masyarakat.

Program kerja yang direncanakan BUMDesa Pandan Harum tahun 2021 salah satunya membuka toko penyedia ATK, rehabilitasi wilayah hutan desa selat, perbaikan dan penambahan jaringan induk.

\section{Visi dan Misi BUMDesa Pandan Harum}

Visi BUMDesa Pandan Harum: Mewujudkan kesejahteraan masyarakat desa selat melalui pengembangan usaha ekonomi dan pelayanan social dengan: "Mari Bersama Membangun Desa Melalui Konsep Tri Hita Karana Menuju Masyarakat Sejahtera". Misi BUMDesa Pandan Harum: pengembangan usaha ekonomi melalui usaha simpan pinjam dan usaha sector riil, pembangunan infrastruktur dasar perdesaan yang mendukung perekonomian pedesaan, mengembangkan jaringan kerjasama ekonomi dengan berbagai pihak, mengelola dana program yang masuk kedesa bersifat dana bergulir terutama dalam rangka pengentasan kemiskinan dan pengembangan usaha ekonomi pedesaan dan Membuka lapangan kerja.

\section{Stuktur Organisasi}

Hasil wawancara dan dokumentasi di peroleh bukti bahwa: struktur organisasi terdiri dari Penasehat: Perbekel desa Selat, Pengawas terdiri dari Ketua dan 2 Anggota, dan Pelaksana Operasional terdiri dari Ketua, Sekretaris dan Bendahara.

Pelaksanaan Pengelolaan Unit Usaha BUMDesa Pandan Harum Desa Selat:

a. Unit simpan pinjam modalnya didapat dari program pemerintah provinsi bali yaitu Gerakan pembangunan Masyarakat Terpadu sebesar Rp 975.000.000,00.

b. BUMDesa Pandan Harum Desa Selat menerima program pelayanan air minum desa melalui Unit Kelompok Pengelola Sanitasi Penyedia Air Minum (KPSPAM) bulan Desember 2019.

c. Unit Usaha Hutan Desa. BUMDesa Pandan Harum dapat melaporkan kegiatan pendataan kawasan hutan dengan tujuan agar dapat data secara periodic dari luasan 
hutan 552 ha yang terlaksana. Hutan yang luasnya 522 ha terdapat dua zona: zona perlindungan dan zona pemanfaatan.

\section{Implementasi Penerapan SAK ETAP}

Hasil observasi dan wawancara yang dilakukan di BUMDesa Pandan Harum memiliki kekurangan dalam penyusunan laporan keuangan yang sesuai dengan SAK ETAP, melainkan BUMDesa Pandan Harum menyusun laporan laba/rugi dan laporan neraca. Sesuai dengan permasalahan yang ada dilapangan diketahui BUMDesa Pandan Harum tidak mampu menerapkan dan menghasilkan laporan keuangan sesuai dengan SAK ETAP karena: 1) Ketidakmampuan sumber daya manusia bahwa mereka tidak paham akan ilmu akuntansi dasar bahkan sulit bagi mereka untuk belajar ilmu akuntansi tersebut. Mereka cenderung tidak paham akan tata cara melakukan pencatatan sesuai dengan SAK ETAP. 2) Latar belakang pendidikan yang dimiliki pegawai sehingga tidak sesuai dengan pembagian tugas khususnya pengawai pendamping BUMDesa yang berlatar belakang SMa sederajat.

Berdasarkan data unit usaha BUMDesa Pandan Harum Desa Selat yang diperoleh untuk implementasi SAK ETAP pada penelitian ini antara lain: buku kas yaitu buku atau catatan yang berisi tentang pengeluaran atau pemasukan kas yang terjadi setiap hari. Pihak BUMDesa mencatat seluruh transaksi keuangannya dalam buku kas tersebut, mulai dari pendapatan (penerimaan kas) dan biaya (pengeluaran kas).

Dalam penelitian ini peneliti memberikan format rancangan laporan keuangan yang sesuai dengan SAK ETAP dan dapat digunakan oleh BUMDesa Pandan Harum Desa Selat untuk membuat laporan keuangan dan memecahkan permasalahan mengenai pencatatan yang berbasis SAK ETAP. Format laporan keuangan yang dibuat yaitu: Laporan Laba/Rugi, Laporan Neraca, Laporan Perubahan Ekuitas, Laporan Arus Kas dan Catatan Atas Laporan Keuangan.

\section{Laporan Keuangan Sesuai Dengan SAK ETAP Pada BUMDesa Pandan Harum Desa Selat Tahun 2020}

Dalam SAK ETAP ada beberapa ketentuan yang dapat dipergunakan sebagai pedoman untuk menyusun laporan keuangan BUMDesa Pandan Harum Desa Selat. Adanya pemisahan asset kedalam asset lancar dan asset tetap dan kewajiban jangka pendek dan kewajiban jangka panjang dalam neraca, pengakuan biaya yang merupakan akibat langsung dari pengakuan asset dan kewajiban dalam laporan laba rugi. Laporan keuangan yang lengkap harus ada laporan neraca, laporan laba/rugi, laporan perubahan ekuitas, laporan arus kas dan catatan atas laporan keuangan. Laporan keuangan BUMDesa Pandan Harum Desa Selat Periode 31 Desember 2020 sesuai dengan SAK ETAP sebagai berikut:

a. Laporan laba rugi memasukkan semua pos penghasilan dan beban yang diakui dalam suatu periode kecuali SAK ETAP mensyaratkan lain. (IAI 2009: 5.2). BUMDesa Pandan Harum Desa Selat selama ini menyusun laporan keuangan khususnya pada laporan laba rugi hanya menyajikan pendapatan dan biaya-biaya yang berasal dari Unit Usaha Simpan Pinjam sedangkan pendapatan dan biaya-biaya yang berasal dari Unit Usaha lainnya seperti Unit Kelompok Pengelola Sanitasi Penyedia Air Minum (KPSPAM) tidak disajikan dalam laporan laba/rugi. Berdasarkan Laporan Laba/Rugi sesuai dengan SAK ETAP untuk jumlah laba setelah pajak sebesar Rp 77.583.792,00.

b. Laporan neraca menyajikan asset kewajiban dan ekuitas pada suatu tanggal tertentu sampai akhir periode pelaporan. Laporan neraca awalnya dibuat kurang tepat karena BUMDesa Pandan Harum Desa Selat dalam menyajikannya tidak semua transaksi yang terjadi di masing-masing unit usaha yang dikelola di BUMDesa disajikan dalam laporan neraca, kemudian peneliti menyajikan laporan neraca yang tepat mengacu 
pada SAK ETAP. Pada SAK ETAP untuk laporan neraca menyajikan semua transaksi yang terjadi di masing-masing unit usaha yang dikelola kemudian digolongkan ke tiga komponen neraca yaitu aktiva lancar, aktiva tetap, kewajiban/utang dan ekuitas, sedangkan BUMDesa Pandan Harum Desa Selat tidak menyajikan secara lengkap transaksi yang terjadi. Pada komponen aktiva lancar, kewajiban dan ekuitas terdapat beberapa transaksi yang tidak disajikan pada laporan neraca contohnya komponen aktiva lancar tidak menyajikan semua jumlah kas di bank. Berdasarkan SAK ETAP jumlah saldo dari masing-masing akun pada laporan neraca yaitu total Aktiva Lancar Rp 1.184.448.931,37, total Aktiva Tetap Rp 357.500,00, total Kewajiban Rp 19.414.271,99 dan total Ekuitas Rp 1.165.392.159,38

c. Laporan Perubahan Ekuitas menyajikan laba atau rugi ekuitas untik suatu periode, pos-pos pendapatan dan beban yang diakui secara langsung dalam ekuitas untuk periode tersebut, pengaruh perubahan kebijakan akuntansi dan koreksi kesalahan yang diakui dalam periode tersebut, dan jumlah investasi, dividend dan distribusi lain ke pemilik ekuitas selama periode tersebut. Selama ini BUMDesa Pandan Harum Desa Selat belum membuat laporan perubahan ekuitas sementara menurut SAK ETAP (2013) pada bab 3 tentang penyajian laporan keuangan dinyatakan bahwa laporan keuangan yang lengkap suatu entitas terdiri dari laporan laba rugi, laporan neraca, laporan perubahan ekuitas, laporan arus kas dan catatan atas laporan keuangan. Berdasarkan laporan perubahan ekuitas sesuai dengan SAK ETAP diperoleh jumlah ekuitas akhir tahun 2020 sebesar Rp 1.242.987.240,38

d. Laporan Arus Kas menyajikan informasi perubahan historis atau kas dan setara kas entitas yang menunjukkan secara terpisah perubahan yang terjadi selama satu periode dari aktivitas operasi, aktivitas investasi dan aktivitas pendanaan. BUMDesa Pandan Harum Desa Selat selama ini belum membuat laporan arus kas dalam penyusunan laporan keuangannya. Berdasarkan Laporan Arus Kas sesuai dengan SAK ETAP, maka jumlah saldo kas 31 Desember 2020 sebesar Rp 1.247.358.002,38

e. Catatan Atas Laporan Keuangan berisi informasi sebagai tambahan informasi yang disajikan dalam laporan keuangan. Menurut Sinarwati (2013:69) catatan atas laporan keuangan harus disajikan secara sistematis, biasanya dilampirkan atau disertakan sebagai pendukung laporan keuangan dasar diantaranya: ringkasan mengenai kebijakan akuntansi, Informasi tambahan mengenai rincian atau penjelasan atas angka neraca, informasi tentang item-item yang tidak dapat dilaporkan dalam laporan keuangan, dan informasi pelengkap lainnya. Catatan atas laporan keuangan BUMDesa Pandan Harum Desa Selat dibuat berdasarkan informasi yang didapat dari BUMDesa yang kemudian telah diolah oleh peneliti dan disesuaikan dengan kaidah SAK ETAP (2009). Catatan atas laporan keuangan BUMDesa Pandan Harum Desa Selat berisi pernyataan bahwa laporan telah disusun sesuai dengan SAK ETAP.

\section{Implikasi Penerapan SAK ETAP Terhadap Laporan Keuangan BUMDesa Pandan Harum Desa Selat}

Laporan keuangan yang sesuai dengan SAK ETAP menyebabkan perubahan pada laporan laba/rugi dan laporan neraca BUMDesa Pandan Harum Desa Selat. Laporan Laba/Rugi BUMDesa Pandan Harum Desa Selat terdapat perubahan yang cukup besar pada beberapa akun. Perubahan tersebut berada pada akun transaksi yang ada di unit usaha kelompok pengelolaan sanitasi penyedia air minum ada beberapa transaksi yang tidak disajikan. Selisih laba yang diperoleh sebelum dan sesudah penerapan SAK ETAP pada laporan laba/rugi BUMDesa Pandan Harum Desa Selat sebesar Rp 46.684.335,00. Selisih tersebut sangat besar dan bisa berdampak terhadap proses pertanggung jawaban laporan keuangan pada anggota dan pemberi pinjaman. 
Laporan neraca BUMDesa Pandan Harum Desa Selat terdapat perubahan pada beberapa akun, perubahan tersebut terjadi karena adanya beberapa transaksi yang tidak dicatat dan diakui periode 31 Desember 2020.

Hasil kesimpulan penelitian berdasarkan proses pertanggungjawaban keuangan diharapkan berjalan dengan lancar. Selain itu, walaupun laporan keuangan yang dibuat secara sederhana dan tidak sesuai dengan SAK ETAP akan tetapi para anggota sudah paham dan mengerti dengan laporan keuangan yang dibuat tersebut. Kemudian dalam proses pertanggungjawaban keuangan, kesimpulan rapat dilaporkan kembali hasil rapat oleh sekretaris agar anggota yang sebelumnya datang terlambat atau kurang jelas bisa memahaminya kembali. Sehingga proses pertanggungjawaban keuangan yang dilaksanakan oleh BUMDesa Pandan Harum Desa Selat sudah bisa dikatakan baik dimana sudah dibuktikan dari laporan yang telah dibuat sebagai alat pertanggungjawaban.

\section{Simpulan dan Saran}

Berdasarkan penelitian yang telah dilakukan mengenai Analisis Penerapan Standar Akuntansi Keuangan Entitas Tanpa Akuntabilitas Publik Pada Badan Usaha Milik Desa Selat Kabupaten Buleleng, maka dapat disimpulkan yaitu 1) Alasan BUMDesa Pandan Harum Desa Selat Belum Menerapkan SAK ETAP pada laporan keuangan karena: a)ketidakmampuan sumber daya manusia pada bagian pendamping BUMDesa yang membuat laporan keuangan tahunan yang tidak paham akan ilmu akuntansi dasar bahkan sulit untuk belajar ilmu akuntansi tersebut dan cenderung tidak paham akan tata cara melakukan pencatatan yang sesuai dengan SAK ETAP, b)kurangnya kesadaran terhadap pentingnya laporan keuangan yang lengkap dan sesuai dengan SAK ETAP, c)keterbatasan waktu dalam penyusunan laporan keuangan karena terkendala di Bank, 2) Penerapan SAK ETAP pada BUMDesa Pandan Harum Desa Selat masih sulit diterapkan, padahal banyak manfaat yang diberikan kepada pihak BUMDesa dalam laporan keuangan. Berdasarkan pembahasan tersebut penerapan SAK ETAP dalam penyusunan laporan keuangan pada BUMDesa Pandan Harum Desa Selat terdiri dari: a) Laporan Laba Rugi, adapun perbandingan antara laporan laba rugi sebelum dan sesudah diterapkannya SAK ETAP yaitu sebelum diterapkannya SAK ETAP laba yang diperoleh Rp 30.899.457,00 sedangkan setelah diterapkannya SAK ETAP laba yang diperoleh $\mathrm{Rp}$ 77.583.792,00. Selisih dari laba rugi sebelum dan sesudah diterapkannya SAK ETAP Rp 46.684.335,00, b) Laporan Neraca sesuai dengan SAK ETAP diketahui jumlah aktiva $\mathrm{Rp} 1.184 .806 .431,37$ dan jumlah pasiva Rp 1.184.806.431,37, c) Laporan Perubahan Ekuitas selama akhir tahun 2020, modal akhir yang diperoleh Rp 1.242.987.240,38. Modal akhir ini diperoleh dari modal awal Rp 1.165.403.268,38 dijumlah dengan hasil laba tahun berjalan sebesar Rp 77.583.972,00, d) Laporan Arus Kas sesuai dengan SAK ETAP diketahui arus kas dari aktivitas operasi Rp 82.104.734,00, arus kas dari aktivitas investasi Rp 150.000,00 dan arus kas dari aktivitas pendanaan Rp 1.165.403.268,38, e) Catatan Atas Laporan Keuangan memberikan penjelasan naratif atau rincian jumlah yang disajikan dalam laporan keuangan dan informasii pos-pos yang tidak memenuhii kriteria pengakuan laporan keuangan. Catatan atas laporan keuangan BUMDesa Pandan Harum Desa Selat berdasarkan informasi yang didapat yang kemudian telah diolah peneliti dan disesuaikan dengan kaidah SAK ETAP. 3) Implementasi penerapan SAK ETAP terhadap laporan keuangan berdasarkan data-data transaksi usaha yang diperoleh yaitu buku kas berisi tentang pengeluaran dan pemasukan yang terjadi setiap hari. Pihak BUMDesa mencatat seluruh transaksi keuangannya menggunakan buku kas tersebut. Maka dari itu peneliti bermaksud memberikan format laporan keuangan yang sesuai dengan SAK ETAP dan dapat digunakan oleh pihak BUMDesa untuk membuat laporan keuangan. Format yang dimaksud: 
laporan laba/rugi, laporan neraca, laporan perubahan ekuitas, laporan arus kas dan catatan atas laporan keuangan.

Mengingat besarnya manfaat yang bisa diperoleh dari penerapan SAK ETAP pada penyusunan laporan keuangan kepada BUMDesa yang belum menerapkannya agar mulai menerapkan akuntansi sesuai dengan standar yang telah ditetapkan. Untuk mengatasi kendala-kendala dalam penyusunan laporan keuangan sesuai dengan SAK ETAP, hendaknya melakukan pendidikan dan pelatihan kepada pengurus BUMDesa dalam hal menyusun laporan keuangan menggunakan SAK ETAP, memilih pengurus yang mau dan mampu untuk belajar baik dalam kegiatan organisasi dan penyusunan laporan keuangan sesuai dengan SAK ETAP.

\section{Daftar Pustaka}

Andriani, Lilya, dkk. (2014). Analisis Penerapan Pencatatan Keuangan Berbasis SAK ETAP Pada Usaha Mikro Kecil Menengah (UMKM) (Sebuah Studi Intrepetatif Pada Peggy Salon). E-Journal S1 Ak Universitas Pendidikan Ganesha, Vol 2 No 1 Tahun 2014.

Bahri, Syaiful. (2016). Pengantar Akuntansi Berdasarkan SAK ETAP dan IFRS. Yogyakarta : Andi

Departemen Pendidikan Nasional. 2017. Buku Panduan Pendirian dan Pengelolaan Badan usaha Milik Desa (BUMDes). Jakarta Selatan : PP-RPDN

Dewi, Putu Eka Dianita Marvilianti dan I Putu Hendra Martadinata. 2018. Akuntansi Koperasi dan UMKM. Singaraja : Universitas Pendidikan Ganesha

Hamzah, A. P., Priharjanto, A., \& Purwanti, D. (2019). Pendampingan Perancangan Kebijakan Akuntansi Berdasarkan Sak Etap Dalam Pelaporan Keuangan Pada Bumdes Tirta Mandiri, Desa Ponggok, Klaten. KUAT: Keuangan Umum Dan Akuntansi Terapan, 1(3), (198-214). https://doi.org/10.31092/kuat.v1i3.634

Ikatan Akuntan Publik Indonesia, (2009). Standar Akuntansi Keuangan Entitas Tanpa Akuntabilitas Publik. Jakarta : Ikatan Akuntansi Indonesia

Lintong, Jerry Sonny, dkk. (2020). Laporan Keuangan Berdasarkan SAK ETAP pada BUMDes "Kineauan" Desa Wawona Kabupaten Minahasa Selatan. Jurnal Bisnis \&Kewirausahaan, Vol. 16 Issue 1. (hlm. 95-101)

Lutfiaazahra, Alifta. (2015). Implementasi Standar Akuntansi Keuangan Entitas tanpa Akuntabilitas Publik (SAK ETAP) Pada UMKM Pengrajin batik Di Kampoeng Batik Laweyen, Surakarta. Skripsi. Surakarta : Universitas Sebelas Maret.

Nusa Bali.com. (2021). Inspektorat Seragamkan Keuangan BUMDes. https://www.nusabali.com/berita/88001/inspektorat-seragamkan-keuangan-bumdes.

Diakses pada 12 Mei 2021.

Sinarwati, Ni Kadek, dkk. (2013). Buku Ajar Akuntansi Keuangan 1 (Berbasis IFRS). Singaraja :Penerbit Universitas Pendidikan Ganesha.

Sinarwati, Ni Kadek, dkk. (2014). Analisis Faktor-Faktor Yang Mempengaruhi Belum Diterapkannya Pencatatan Keuangan Berbasis SAK ETAP Di UMKM (Studi Kasus 
UMKM Di Kabupaten Buleleng). Jurnal Akuntansi, Vol. 02 No. 01, (hlm. 07-17).

Sinarwati, Ni Kadek dan AAIN Marhaeni. (2019). "The Role Of Village Own Enterprises to Rural Development". South East Asia Journal of Contemporary Business, Economics and Law, Vol. 18, Issue 5 (February). ISSN 2289-1560.

Sinarwati, Ni Kadek. (2021). Penguatan BUMDes Pasca PP No. 11 Tahun 2021. https://posmerdeka.com/penguatan-bumdes-pasca-pp-no-11-tahun-2021/, Diakses pada 12 Mei 2021

Sugiyono. (2015). Metode Penelitian Pendidikan, Pendekatan Kuantitatif, Kualitatif dan $R \& D$. Bandung : Alfabeta

Wiadnyana, I Putu Oka, dkk. (2017). Penyusunan Laporan Keuangan Berdasarkan Standar Akuntansi Keuangan Entitas Tanpa Akuntabilitas Publik (SAK ETAP) Pada Usaha Mikro Kecil Menengah (Studi Kasus UD. Adhikari Mandiri). e-Journal S1 Ak Universitas Pendidikan Ganesha, Vol 8 No. 2 Tahun 2017. 